\title{
Büntetőjogi dogmatika a Debreceni Ítélőtáblán a 20. század első felében
}

1. A kiegyezést követően helyreállított magyar alkotmányosság lehetővé tette az áprilisi törvények szellemében a polgári államberendezkedés kiépítését, és jogrendszerünk polgári értelemben vett átalakítását. ${ }^{1}$ Jogrendszerünk 19. századi modernizációs törekvését két tényező hatotta át. Egyrészt a neoabszolutizmus időszakában bevezetett - mértékekkel haladóbb - osztrák jogot az Ideiglenes Törvénykezési Szabályok nagyrészt elvetették, azonban az osztrák jog a magyar bírói gyakorlatban számos helyen tovább élt, így annak hatása a kiegyezést követően is megfigyelhetö. Másrészt az egyes jogterületek kodifikációja eltérő ütemben haladt, így a büntető és anyagi magánjogot átfogó kódexek sem egy időben készültek el.

A modern büntetőjog tekintetében mindez az 1878:V. tc-ben - továbbiakban Csemegi-kódex - és az 1896:XXXIII. tc-ben nyilvánult meg. A Csemegi-kódex, mint az első magyar kodifikált büntetőtörvénykönyv a 19. század tendenciáinak megfelelően, egy modern jogalkotási termék, amely az idők próbáját is kiállta, hiszen az általános része 1950-ig, míg a különös része 1961-ig volt hatályban.

Csemegi Károlynak, mint kodifikátornak a 19. század meghatározó büntetőjogi irányzatainak a sodrában kellett döntenie és érvelnie a kódex fő irányvonalát illetően. A jogalkotó végül a klasszikus büntetőjogi irányzat mellett döntve, a korabeli jogalkotás német orientációjához igazodva, határozta meg a törvény foobb alapelveit. A büntetőjogi irányzatok determinálják a törvény alapelveit, s azok által a tételes rendelkezések fényében a gyakorlatban is kifejezésre jutnak. ${ }^{2}$ A klasszikus büntetőjogi irányzat tettbüntetőjogi szemléleten alapul, amely értelmében a büntetőjogi felelősség középpontjában az elkövetett cselekmény állt. Ez a szemlélet tehát az elkövetett cselekményre, - amely tevés vagy mulasztás is lehet - mint a külvilágban bekövetkezett változásra, és elsősorban nem az elkövető alanyi oldalára

\footnotetext{
${ }^{1} \mathrm{Az}$ áprilisi törvények angol és magyar nyelvü szövegváltozatát kommentárral ellátva, lásd bövebben: VARGA NORBERT: Reformtörvények Magyarországon 1848-ban = The Acts of 1848 in Hungary. Szeged, 2012.

${ }^{2}$ Vö.: P. SZABÓ BÉLA: Bernolák Nándor, az I. büntető novella egyik kodifikátora és kommentátora. Jogtörténeti Szemle (2008) 4. sz. 12-20.; MEZEY BARNA: Ami az I. büntető novellából kimaradt. Jogtörténeti Szemle (2008) 4. sz. 34-40; MADAI SÁNDOR: A csalás tényállása a Csemegi-kódex és az I. Büntető novella tükrében. Jogtörténeti Szemle (2008) 4. sz. 21-28.
} 
helyezte a hangsúlyt. ${ }^{3}$ Mindez a kódex egész rendszerén következetesen érvényesült, hiszen már az általános rész is rögzíti, hogy „büntettet vagy vétséget csak azon cselekmény képez, amelyet a törvény annak nyilvánít."4

Ebből adódóan a klasszikus iskola tanaira épülő kódex merev dogmatikai irányvonalat képviselt, amelyet keletkezésekor nem készítettek fel azokra a 20. századi kihívásokra, amelyekkel Európa valamennyi államának szembe kellett néznie.

A tanulmány a továbbiakban a Debreceni Ítélőtábla két világháború közötti peranyaga alapján tárja fel azokat a körülményeket, amelyek hozzájárultak a kódex merev rendszerének a lazításához. A 20. század második évtizedeihez érve a büntető ítélkezési gyakorlatban a korábbi évtizedekhez képest változás következett be. A két világháború közötti ítélkezési gyakorlatot megvizsgálva megállapítható, hogy az „következetlenül következetes” volt. Következetlen, mert a Csemegi-kódexben meghatározott büntetési nemektöl és tételektől - még a középmértékes büntetéskiszabást alapul véve is - a ténylegesen kiszabott büntetés jelentős mértékben eltérnek. Azonban következetes is, mert az eltérést minden esetben ugyanolyan logika alapján tanúsítja a bíróság. Az említett ítélkezési gyakorlat okát egyrészt a korszak sajátos történelmi okaiban (szociológiai körülmények), másrészt a jogtudományban bekövetkezett változásban látom.

2. A korszak sajátosságából eredő körülmények azon történelmi események összejátszása, amelyek alapjaiban határozzák meg a '20-as évek társadalmi, gazdasági helyzetét Magyarországon. Az Osztrák-Magyar Monarchia felbomlása és a trianoni békeszerződés súlyos gazdasági, társadalmi krízist okozott. Ezt fokozta az I. Népköztársaság és Tanácsköztársaság alatti vörös-, illetve fehérterror, továbbá a világháború kriminalitásra gyakorolt hatása. A háború kezdetben mindig kedvezően hat a bünözésre, majd az idő előrehaladtával eléri a békeidőbeli szintet. Hosszan elhúzódó háború pedig kifejezetten kedvezőtlen, amelynek negatív hatása a háború utáni években is érzékelhető. ${ }^{5}$ Ennek oka a háború gazdasági szférára gyakorolt hatása, amely miatt a gazdaság eltorzul, az élelmiszerellátás akadozik, ami önmagában csökkenti a társadalom kriminális csábításokkal szembeni ellenálló képességét. Ezt támasztják alá a korszakból származó statisztikai adatok is, melyek szerint az élet elleni büncselekmények száma 1921-ben 170, 1922-ben 188, 1923ban 213, 1924-ben 227, 1925-ben 209, 1926-ban 184 db volt. ${ }^{6}$ Ezek alapján megfigyelhetö, hogy az 1923 és 1924-es években volt legmagasabb a kriminalitás, a háború kriminális hatása ekkor vetült ki igazán a társadalomra. Mindezeken túl a bünözési hajlandóságot a kulturális, vallási tényezők és a müveltség is befolyásolta. Általánosságban elfogadható, hogy a magasabb iskolai végzettség könnyebb megélhetést biztosít, így e körben alacsonyabb a kriminalitás. Ezzel szemben

\footnotetext{
${ }^{3}$ Ezzel ellentétben a korábbi - 1843. évi törvényjavaslat - nem a cselekményre, hanem a cselekvésre helyezte a hangsúlyt.

${ }^{4} 1878$ :V. tc. 1 . .

${ }^{5}$ HACKER ERVIN: Háború hatása a kriminalitásra. Miskolc, 1940. 1.

${ }^{6}$ Magyar Statisztikai Évkönyv. Új Folyam 27-30. k. (1919-1922), Bp., 1925. 240-259.; uo. 31-33. kötet (1923-1925) Bp., 1927. 305-331; uo. 34. k. (1926), Bp., 1928. 283-296.
} 
Magyarországon azt tapasztaljuk, hogy a tárgyalt korszakban az írni-olvasni tudók körében magasabb a bünözési hajlam, mint az analfabéták körében. Mindez azzal magyarázható, hogy a kisebb kriminalitású nők között kisebb az írni-olvasni tudók aránya is.

A korszak sajátosságai mellett a jogtudományban bekövetkezett szemléletbeli változás is hatással volt a jogalkalmazásra. A 20. század elején hazánkban is egyre nagyobb teret hódított a pozitivista illetve közvetítő irányzat, mely a kódex tettbüntetőjogi szemléletével több ponton ellentétes is volt. A szemléletbeli változás részben nyomon követhető a kódex novelláris módosításaiban is, azonban azok azt nem felülírták, pusztán csak kiegészítették, és a törvény hiányosságait pótolták. Ez a kettősség eredményezte a „következetlenül következetes” ítélkezési gyakorlatot, amely a bünösség és a büntetéskiszabás elvein keresztül érvényesült a legszemléletesebben.

3. A bünösség a büncselekmény egyik fogalmi eleme, amely az elkövető szubjektuma és a külvilágban bekövetkező változás közötti okozati összefüggés kifejezésére irányul. Attól függően, hogy ez az okozati összefüggés mennyire szoros, megkülönböztetjük a bünösség két alakzatát: a szándékosságot és a gondatlanságot. Mindez a korabeli felfogás értelmében azt jelentette, hogy szándékosan követi el a büncselekményt az, akinek tudata átfogja a véghezviteli magatartás kifejtésekor a tényállás jogellenességi elemeihez tartozó körülményeket. Míg gondatlanul követi el a büncselekményt az, aki nem fejtette ki a tőle elvárható gondosságot, amivel a büncselekmény megelőzhető lett volna. Ebből adódóan a szándékosság súlyosabban, míg a gondatlanság enyhébben ítélendő meg. Mindezt a jogalkotó is érvényre jutatta, ami a kódex felépítésében két értelemben figyelhető meg. Egyrészt a büntett csak szándékos lehet, - ebből adódóan büntettet gondatlanul elkövetni nem lehet - másrészt a gondatlanul elkövetett vétség is csak akkor büntethetö, ha a gondatlan elkövetést a törvény kifejezetten büntetni rendeli. Azt azonban, hogy mit értünk szándékosság vagy gondatlanság alatt, a Btk nem határozta meg, annak kimunkálása a jogtudományra és a bírói gyakorlatra hárult.

Tekintettel a dogmatikai változásokra, mindez a bünösség alakulása kapcsán két síkon is jelentkezett. Egyrészt a törvény rendelkezésein túl a gondatlan elkövetést a bíróságok is enyhébben ítélték meg. Az élet elleni büncselekmények körében mindez a cselekménnyel okozott kár vagy veszély „háttérbe szorításával” járhatott. ${ }^{7}$ Ugyanis a gondatlanságból elkövetett vétségeknél, különösen ha az halállal járt, a cselekménnyel vagy mulasztással okozott kár ugyanaz volt mint a szándékos emberölésnél. Ezt azonban rendre jelentősen háttérbe szorította az elkövető alanyi bünösségének csekély súlya. ${ }^{8}$ Ezen túl a gondatlan alakzatot maga a kódex egy kivételtől eltekintve tovább nem bontotta ki, azonban az ítélkezési gyakorlat

\footnotetext{
${ }^{7}$ Magyar Nemzeti Levéltár Hajdú Bihar Megyei Levéltára (a továbbiakban MNL HBML) VII. 2/b. 35. d. 2077/1921.

${ }^{8}$ FINKEY FERENC: Szemelvények kisebb szakdolgozataimból 1890-1940. Bp., 1940. 14.
} 
különbséget tett a gondatlanság egyes alakzatai között. ${ }^{9}$ Másrészt a bünösség mindkét alakzatának további kibontása az elkövetői szubjektum egyes mozzanataira vezethető vissza.

A bünösség leglazább alakzata értelmében az elkövető magatartása jogellenességét azért nem ismerte fel, mert nem járt el kellő körültekintéssel (hanyag gondatlanság). ${ }^{10}$ Ettől szorosabb kapcsolatot feltételez a tudatos gondatlanság, amely értelmében az elkövető tisztában van magatartása jogellenességével, azonban könnyelmüen bízik a káros eredmény elmaradásában. (tudatos gondatlanság). ${ }^{11}$ Ebböl következik, hogy szándékosságról csak akkor beszélhetünk, ha az elkövető akarata kifejezetten kiterjedt a káros eredmény bekövetkezésére. Amennyiben ezt kívánta is, akkor egyenes szándékról, amennyiben nem kívánta csak belenyugodott, akkor eshetőleges szándékról beszélünk. A Csemegi-kódex nem értékelte a szándékosság két alakzata közötti különbséget, így az összes büncselekmény kivéve azok, amelyek csak gondatlanul követhetőek el - akár eshetőleges szándékkal is megvalósítható volt. Ez alól kivételt az emberölés tényállásai jelentettek, ahol a jogalkotó külön tényállásban szabályozta a szándékos (eshetőleges) emberölést, és a gyilkosságot. Ez utóbbi az előre megfontolt szándékból (egyenes) elkövetett emberölést jelentette. Így a két tényállás között az elkövető, a sértett, az elkövetési magatartás, de még az eredmény is azonos volt. Különbséget - a büntetési tételen túl - csak az előre megfontoltságban látunk.

Ennek súlyosabb értékelése az emberölés kapcsán nem újkeletü, hiszen a rendi büntetőjogunk is ismerte a gonoszsággal, elöre megfontoltan elkövetett un. praemediált emberölést (homicidium ex praeconcepta malitia). ${ }^{12}$ aminek sajátossága, hogy az elkövetö tettét elöre elhatározza és meg is fontolja.

H. Mihály két testvérével, édesanyjával és nagymamájával lakott együtt. A vádlott azt szerette volna, hogy a közös lakásuknak a sértettekre esö tulajdoni hányadát megvásárolja, és így külön családot tud alapítani. Földjüket pedig közösen müvelik. A sértettek ebbe nem egyeztek bele, ami hónapokon át tartó veszekedéshez vezetett. A viták következtében a kapcsolat a vádlott és a sértettek között megromlott, majd odáig fajult, hogy a vádlott nagymamáját és két testvérét, a ház, illetve a föld megszerzése végett megölte. ${ }^{13}$

A perbeli tényállás szerint az elkövető a tettét előre elhatározta, hiszen az elkövetésre irányuló szándék és a tényleges kivitelezés között elegendő idő telt el. A korabeli irodalomban is komoly vitára adott okot annak az eldöntése, hogy pontosan mennyi idő elteltére van szükség az előre megfontoltság megállapításához. Finkey

\footnotetext{
${ }^{9}$ A gondatlanság speciális alakzatai közzé tartozott az az eset, ha a halál az azt okozónak hivatalában, tudományában, iparágában vagy foglalkozásában való járatlanságából vagy hanyagságából eredt.

${ }^{10} \mathrm{~A}$ szakirodalomban mindez távoli vétkességként (culpa remota) jelentkezett. Vö.: SCHNEIDER ALADÁR: A büntetőjog általános tanai, Bp., 1888. 149.

${ }^{11}$ A szakirodalomban mindez közeli vétkességként (culpa proxima) jelentkezett. Uo. 147.

${ }^{12}$ Vö.: 1486:LI. tc. A 19. századi törvényhozásokra általánosan jellemző a praemediált és nem praemediált emberölések közötti különbségtétel. Vö.: 1872. évi német birodalmi büntetőtörvénykönyv 211. §.

${ }^{13}$ MNL HBML VII. 2/b. 38. d. BII. 2937/1924.
} 
szerint az elhatározáshoz szükséges idő személyenként változik, de semmiképpen sem szükséges több nap. ${ }^{14}$ A Kúria még tovább ment, mikor kimondta, hogy a , [...] az elkövetésre használt fegyver beszerzése és a tett elkövetése között lefolyt jelentékenyebb idötartam[..]" elegendő az átgondoltság megvalósításához. ${ }^{15}$ Fontos kiemelni, hogy az időmúlásnak az akarat és a tényleges kivitelezés között, csak akkor van jelentősége, ha az akarat megegyezik a tényleges kivitelezéssel. Így „a vádlott férj szándéka akkor, amikor a pisztolyt magához vette és $H$. P. lakásán tartózkodó nejéhez elment, nem határozottan és egyenesen neje megölésére, hanem elsö sorban kibékítésére volt irányozva, és azon esetre, ha a kiengesztelés nem sikerül, tehát <in eventum> lebegett elötte a gondolat, hogy nejét megöli. ${ }^{16 "} \mathrm{~A}$ perbeli tényállás értelmében ez az az akarat egyező volt és a hónapokon át tartó veszekedés mindenképpen kellő időnek minősíthető. Ahhoz azonban, hogy az emberölés gyilkosságnak minősüljön, nem elég az, hogy az elkövető tettét elöre elhatározza, hanem a megfontolás is szükséges. ${ }^{17}$ A megfontoltságot a fent említett ügyben két tényező is igazolta. Egyrészt a vádlott az elkövetés előtti éjjel azt mondta barátjának, hogy S. J-nél lesz az elkövetés éjszakáján, azaz alibit szerzett magának. Másrészt tettét álcázni próbálta azzal, hogy az elkövetés eszközeit elrejtette, és a lakásban lévő ruhákat szétdobálta, illetve az ajtót felfeszítette, hogy a cselekmény rablásnak tünjön.

Mindezek alapján általánosságban megállapítható, hogy a két világháború közötti ítélkezési gyakorlat alapján az előre megfontoltságot a tervszerüség, ${ }^{18}$ higgadt, hidegvérü végrehajtás ${ }^{19}$ jellemzi, ahol az akarat megszületése és a kivitelezés között egy minimális időtartamnak kellett eltelnie.

Sajátosan alakul a bünösség kérdése több személy által akarategységben elkövetett büncselekmény során. Ilyen esetben mérvadó, hogy a felek akarata mire terjed ki, de jelentősége lehet annak is, hogy akaratuk következtében milyen magatartást fejtettek ki. Mindez valójában a tettesség-részesség elhatárolását jelenti a bünösség alapján. Nem vet fel különösebb értelmezési problémát az az eset, amikor az elkövetők akarategységben ugyanazt az elkövetési magatartást fejtik ki. Ilyenkor minden elkövető ugyanazon büncselekményért vonható felelősségre. ${ }^{20}$

\footnotetext{
${ }^{14}$ FINKEY FERENC : A magyar büntetöjog tankönyve. Bp., 1914. 197.

${ }^{15}$ C. 1891/1500. EDVI ILLÉS KÁROLY (szerk): Grill-féle döntvénytár. Bp., 1905, 438.

${ }^{16}$ C. 1881/7204. Uo. 455.

${ }^{17}$ ANGYAL-ISAÁK: Büntetötörvénykönyv I. Bp., 1941. 281.

${ }^{18}, A$ vádlott többek társaságában feküdt le, s megvárta míg ezek elaludnak s ezáltal biztosította magát az iránt, hogy áldozatát védtelen állapotban találja [...] Továbbá előre bizonyítékot akart biztosítani magának a végzetes éjjel való holléte igazolása iránt” $\mathrm{C}$. 1882/144. Grill-féle döntvénytár. Bp., 1905, 438.

${ }^{19}$ „[...] igaz, hogy I. $r$. vádlott a kocsmából hazőjve némileg ittas állapotban volt, akkor amikor a mérget férje ételébe keverte, az is igaz, hogy a férje korholó szavai hatására követte el a cselekményt. Tekintettel azonban arra a kitartásra, mellyel I. $r$ vádlott hetekig tartó rábeszéléssel II. $r$ vádlottat a méreg beszerzésére rávette [...] az elöre megfontolt szándék kétségtelen.” C. 1896/4710. Grill-féle döntvénytár. Bp., 1905, 438.

${ }^{20} \mathrm{Ez}$ nem jelenti azt, hogy a büntetésük is azonos esz, hiszen a büntetés mértékét az enyhítő és súlyosbító körülmények is befolyásolják.
} 
Leflér és társai, illetve a sértett között közös italozás és mulatozás közepette nézeteltérés támadt, ami tettlegességig fajult. A támadók négyen voltak, és dulakodás közben a sértettet többször megütötték, aki így a földre került. Majd miután felállt egy baltával mellbe vágták, és egy lovat hoztak. Ezt követöen a sértett hóna alá egy kötelet tettek, az a hámhoz rögzítették és kb. 270 lépésnyire lévó házához elvontatták. Több orvosszakértö egybehangzó véleménye alapján a sértett halálát ezen cselekmények okozták, különösen a mellkason elszenvedettek. ${ }^{21}$

A perbeli tényállás alapján az elkövetők szándékegységben ugyanazt a magatartást fejtették ki, így társtettességben ugyanazon büncselekményért voltak felelősségre vonhatóak.

Más a helyzet akkor, amikor a felek akarategysége megvan, de az egyik fél tevékenysége nem konkrétan az elkövetési magatartás kifejtésére irányul.

H. Józsefnek F. Verától született Sándor nevü gyermekük. Kapcsolatuk megromlott, így a felek külön éltek, de a férfi tartásdíjat fizetett. Idöközben a férfi megismerkedett Gy. Erzsébettel (15-16 éves), akivel szerelmi viszonyt alakított ki. A vádlottak közösen tervezték el a gyermek megölését azért, hogy a tartásdíj fizetése alól mentesüljenek. $^{22}$

A gyermeket 30-40 db kockacukor nagyságú lúgkővel ették meg, azonban magát az elkövetési magatartást ténylegesen a nő fejtette ki. A bizonyítási eljárás során a bíróság megállapította, hogy az elkövetési magatartás ötlete, legalábbis a megvalósítás tekintetében a férfitôl eredt. ${ }^{23}$ Azonban az elkövetés tényleges kivitelezését a nő végezte, így a férfi felbujtónak (részes) minősült, hiszen az ő magatartásának következtében - kijelentései, a terv kidolgozása - alakult ki a nőben az elkövetésre irányuló szándék. A bíróság a férfit gyilkosság büntettére való felbujtásban találta bủnösnek. Mindez némileg ellentmond a Kúria 1914. július 14-ei elvi állásfoglalásának, mely értelmében gyilkosságnál az elöre megfontolt szándék a részesre ki nem terjedő körülmény. Nem ellentmondó az ítélet, ha elfogadjuk, hogy a szándék oszthatatlan és személyes körülmény, így a tettes elöre megfontolt szándéka a részesre nem terjed ki, azonban nem is zárható ki az sem, hogy a részesnél az előre megfontoltság önállóan is jelentkezzen. Ebből adódóan a kúriai állásfoglalástól való eltérést az ítélőtábla a férfi személyéből fakadó okból vezette le.

Szintén sajátosan alakul a bünösség megítélése az erős felindulásban elkövetett emberölés esetén. ${ }^{24}$ Amikor a vádlottak az eljárás során erős felindulásra

\footnotetext{
${ }^{21}$ MNL HBML VII. 2/b. 43. d. 497/70/1924.

${ }^{22}$ MNL HBML VII. 2/b. 43. d. 921/47/1924.

${ }^{23}$ Érdekesség, hogy a bizonyítás során a bíróság kulcsfontosságú szerepet tulajdonított annak a tanuvallomásnak, mely szerint egy alkalommal a férfi azt mondta a gyermekéről, hogy „, bár meghalna, de nem viszi el azt az Isten se.”

${ }^{24} 1878$ :V. tc. 281. § „Ha a szándéka tettesnek erös felindulásában keletkezett és rögtön végre is hajtatott: az emberölés tiz évig terjedhetö fegyházzal büntetendö.Ha pedig az erös felindulást az okozta, hogy a megölt személy a tettest vagy hozzátartozóit jogtalanul sulyosan bántalmazta, vagy megsértette, az emberölés ezen felindulásban rögtön végre is hajtatott: a büntetés öt évig terjedhetö börtön leend"
} 
hivatkoztak, akkor valójában a bünösségük fokán próbáltak enyhíteni. ${ }^{25} \mathrm{Az}$ erős felindulás az ingerültségnek és lelki izgalomnak egy olyan magas foka, amely elhomályosítja (beszükíti) a tudatot és ezáltal az elkövető nem tud szabadon mérlegelni. Ebből adódóan az erős felindulásban elkövetett emberölést a jogalkotó is enyhébben ítélte meg. ${ }^{26}$ Jogszabályból eredő további enyhítő körülmény, ha az erős felindulást az okozta, hogy a sértett az elkövetőt vagy annak hozzátartozóját bántalmazta, kivéve, ha a „bántalmazás semmi féle testi nyomot nem hagy. "27 A 281. § szó szerinti értelmezésénél fogva nem zárható ki, hogy az erős felindulást kiváltó ok abban keresendő, hogy a sértett az elkövető vagyona ellen intéz támadást. Az irodalom ebben a kérdésben nem volt egységes, azonban a gyakorlatban találunk rá példát. A Nyíregyházi Törvényszék egy csutkagomolya ellen intézett jogtalan támadást alapos oknak találta az erős felindulás megállapításához, pedig az nem is a vádlott tulajdonában volt, ő csak őrizte. Az ítélőtábla a minősítést fenntartotta, azonban a büntetéskiszabás során nem ítélte olyan nyomatékos enyhítő körülménynek. Az erős felindulásra való hivatkozás további érdekessége, hogy az oknak a sértett személyében kell gyökereznie.

\section{Sz. Lászlóné egy zsinorral folytotta meg édesanyját és hogy titkolja tettét önakasztásnak álcázta. ${ }^{28}$}

A törvényszék nem találta megalapozottnak az erős felindulást, mivel a vádlott először lefeküdt, és csak utána követte el a büncselekményt, azaz volt ideje átgondolni. Az ítélőtábla is hasonló eredményre jutott, azonban más érvelés által. Az ítélőtábla az erős felindulás megállapítása során mindig az elkövetés valamennyi körülményeit vizsgálta. Jelen esetben a zsinór, mint elkövetési tárgy volt az, amely kizárta az erős felindulás lehetőségét. Ez az állapot elhomályosítja a tudatot, ezért az elkövető nem gondolkozik, és nem is gondolkozhat azon, hogy mivel követi el a büncselekményt. A bíróság érvelése szerint, ha a vádlott tényleg erős felindulásban lett volna, akkor valószínűleg puszta kézzel folytja meg édesanyját. ${ }^{29}$

4. A következetlenül következetes ítélkezési gyakorlat a bünösség sajátos megítélése mellett a büntetéskiszabás elveiben is nyomon követhető. A büntetés kiszabása során kulcsfontosságú, hogy miért büntet a bíró és mi alapján mérlegel. Ezekre a kérdésekre adnak választ a büntetési elméletek, melyek két fö áramlat mentén jellemezhetőek: megtorlási elmélet és a célbüntetési elmélet.

A klasszikus iskola tanai szerint - amelyre a kódex is épül - a büntetés célja a proporcionális megtorlás. ${ }^{30} \mathrm{Ez}$ az elmélet azonban tisztán csak ott alkalmazható,

\footnotetext{
${ }^{25}$ MNL HBML VII. 2/b. 34. d. 2218/1921.; 2826/1921.; 36. d. 1150/1922.; 964/1922.; 42. d. 2324/1923.

${ }^{26}$ BALÁs ELEMÉR: A magyar büntetöjog tankönyve. Bp., 1901. 95.

${ }^{27}$ KAUTZ GUSZTÁv: A magyar büntetöjog gyakorlati kézikönyve. Bp., 1927. 514.

${ }^{28}$ MNL HBML VII. 2/b. 42. d. 2368/1923.

${ }^{29}$ Hasonló érvelés: MNL HBML VII. 2/b. 34. d. 2826/1921., 2218/1921.

${ }^{30}$ A büntetés céljáról lásd bővebben: SIPOS FERENC: A büntetés céljának változásai a magyar büntetö anyagi jogban a Csemegi-kódextől az 1978.évi IV. törvényig, P. Szabó Béla, Szemesi
} 
ahol a büntetés egyenlő büncselekménnyel okozott hátránnyal (malum). Jelen esetben a kérdés azt jelentené, hogy ha valaki megöl/súlyosan bántalmaz valakit, akkor az ő halála igazságos megtorlás-e? A középkori büntetőjogra jellemző puritanizmis a 20. század modern felfogásában így nyilván nem értelmezhető, ezért a megtorlási elv a modern büntetőjogban valójában azt jelenti, hogy a büntetésnek azt az értékét kell megkeresni, amely a büncselekménnyel okozott kárnak leginkább megfelel. ${ }^{31} \mathrm{Az}$ emberölés esetén a tisztán megtorló elv alkalmazásának további akadálya, hogy maga a szemlélet nép eredetü. A középkori, de még a 19-20. századi társadalmi felfogás szerint az emberölés „méltó” büntetése a halálbüntetés. A megtorló elv értelmében a büncselekmény eredményét kell megbosszulnia a büntetésnek és nem magát a büncselekményt, amely önmagában nem tenné lehetővé a bünösség érvényre juttatását a büntetéskiszabás során. Ezt a bírói gyakorlat kezdetben úgy hidalta át, hogy szubjektív elemeket, különösen a motívumot is hangsúlyosabban kezdte értékelni. A célbüntetési elmélet értelmében a büntetés akkor elfogadható, ha valamilyen haszonnal jár, ami a megelőzésben ölt testet. E prevenció lehet generális és speciális is, mely utóbbi alatt az elkövetőre személyére szabott, és általában határozatlan tartalmú büntetéseket értjük. Csemegi Károly a kódex megalkotásakor úgy nyilatkozott, hogy „sem az abszolút, sem a relatív teória, sem az erkölcsi igazság elve magában, s így nem is egyedül a bünhödés, de nem is magában a hasznosság [...], sem egyike ama külön-külön céloknak melyek a relatív elméletek kizárólagos célja” ${ }^{32}$ nem szolgálhat a büntetés céljául. ${ }^{33}$ Ebből adódóan a büntetés kiszabása során kizárólag egyik elméletre támaszkodni nem lehet, amelyet Finkey Ferenc úgy értelmezett, hogy a cél az igazságos represszió és a céltudatos prevenció. $^{34}$

A relatív büntetési rendszer értelmében a törvény által biztosított keretek között a bíró az enyhítő és súlyosbító körülmények figyelembevételével szabja ki a büntetést. E körülményeket azonban a kódex nem sorolta fel, így azok kimunkálása az ítélkezési gyakorlat feladata volt. ${ }^{35}$ A büntetéskiszabásához segítségéül egyedül a Kúria 1885/49. számú döntvénye nyújthatott segítséget, amely meghatározta az un. középmértékes büntetéskiszabást. Ennek értelmében, ha sem súlyosbító sem pedig enyhítő körülmény nem áll fenn, akkor a normális büntetés a középmérték pontján lévő büntetés. Ezt a büntetési nem általános minimumából és a konkrét tényállásban elöírt büntetési tétel maximumából számítják ki úgy, hogy a speciális minimum és maximum középpontjához hozzáadják a speciális és általános minimum közötti

Sándor (szerk): Profectus in Litteris 3, Debrecen, 249-256; SIPOS FERENC: Determinizmusindeterminizmus-predestinatio. Jogelméleti Szemle, (2011) 2. sz. 1.

${ }^{31}$ HeLler ERIK: Adalékok a büntetéskiszabás alapvető kérdéseihez. Bp., 1914, 174.

${ }^{32} \mathrm{Az}$ 1875. évi augusztus hó 28-ra hirdetett Országgyülés Képviselőházának Irományai. V. k. Bp., 1876. 141. 200. sz.

${ }^{33} \mathrm{Az}$ abszolút büntetési elméletről lásd bőveben: SIPOS FERENC: A abszolút büntetési elméletek. Profectus in Litteris 4. Szerk.: P. Szabó Béla, Szemesi Sándor. Debrecen, 2012, 197-204.

${ }^{34}$ FINKEY FERENC: Büntetési rendszerünk egyszerüsítése. Bp., 1904. 14.

${ }^{35}$ FINKEY FERENC: Motívumok értékelése a legújabb büntető törvényjavaslatokban. Jogászegyleti Értekezések, (1910) 10. f. 475. 
különbséget. ${ }^{36} \mathrm{Ez}$ a középmérték az, amelyhez képest az enyhítő és súlyosbító körülmények alapján a bíró a speciális minimum vagy maximum felé elmozdulhat. ${ }^{37}$

A hirtelen harag (erős felindulás) gyakran szerepelt az enyhítő körülmények között. Így a vádlott esetében enyhítő körülményként értékelte a bíróság azt, hogy a hirtelen haragot az váltotta ki, hogy a sértett többször lopott, de utolsó alkalommal rajtakapták. ${ }^{38} \mathrm{~A}$ hirtelen haraghoz tartalmilag hasonló enyhítő körülmény volt a szóváltás következtében történő erős felindulás. ${ }^{39}$

A két leggyakrabban előforduló enyhítỏ körülmény a büntetlen elóélet ${ }^{40}$ és a vádlott beismerő vallomása ${ }^{41}$ volt. Ezek kívül a bíróság több esetben is enyhítő körülménynek minősített, olyan körülményeket, amelyek a klasszikus iskola tanaitól való elszakadásra utalnak.

A vádlottak egy lakodalom alkalmával a mulatozók között felismerték régi haragosaikat, akikre szóváltás után rátámadtak. H. Márton egy késsel többször is megszúrta az egyik sértettet, H. Imre pedig elöször a szétválasztás, késöbb pedig testvére megsegitése céljából avatkozott be. ${ }^{42}$

A bíróság enyhítő körülményként értékelte, hogy a vádlott maga is megsérült, továbbá azt, hogy lakodalom volt, $\mathrm{s}$ így mindenki sokat ivott. ${ }^{43} \mathrm{Az}$ alkoholfogyasztás megítélésében a 20. század első évtizedeiben ment végbe jelentős változás, s a bírói gyakorlat egyöntetü abban, hogy az alkoholfogyasztás következtében beállott tudatzavar, nem azonos a tudat teljes hiányával, így azt büntethetőséget kizáró okként értelmezni nem lehet. Ez azonban az említett példák alapján nem jelentette azt, hogy a '20-as években a bíróság enyhítő körülményként ne vegye figyelembe. A beszámítási képesség kérdéséhez kapcsolódó enyhítő körülmény a vádlott gyenge ítélőképessége vagy fogyatékossága, ${ }^{44}$ társadalmi állása alapján pedig a nagycsalád ${ }^{45}$ és az alacsony iskolázottság ${ }^{46}$ is figyelembe vehető volt.

Általánosságban elmondható, hogy a bíróság az enyhítő körülmények jelentős részénél a vádlott alanyi oldalát értékelte, s ezáltal következetesen, de mégis a kódex tételes rendelkezésein lazítva járt el a büntetéskiszabás során.

Bár közel sem annyira nyomatékosan, de a súlyosbító körülmények értékelése során is felfedezhetjük a klasszikus iskola elképzeléseitől való távolodást, ugyanis

\footnotetext{
${ }^{36}$ Lásd bővebben: MEZEY BARNA: Bünözés és Büntetésvégrehajtási jog a századfordulón. Jogalkotás és jogalkalmazás egyes kérdései Magyarországon a 19-20. században. Szerk.: Kovács Kálmán. Bp., 1986. 117.

${ }^{37}$ VÁMBÉRY RUSZTEM: A büntetőjog. Bp., 1913. 148.

${ }^{38}$ MNL HBML VII. 2/b. 35. d. 359/1922.

${ }^{39}$ Uo. VII. 2/b. 34. d. 1307/1920; 36. d. 1150/1922.; 42. d. 2324/1923.

${ }^{40}$ Uo. VII. 2/b. 34. d. 2218/1921.; 42. d. 2324/1923.; 44. d. 657/1925.

${ }^{41}$ Uo. VII. 2/b. 32 d. 3490/1922.; 36. d. 366/1922.; 38. d. 2937/1924.; 43. d. 497/1924.

${ }^{42}$ Uo. VII 2/b. 34. d. 2218/1921.

${ }^{43}$ Hasonló ítélet: MNL HBML VII. 2/b. 34. d. 2826/1921.

${ }^{44}$ MNL HBML VII. 2/b. 42. d. 2368/1923.

${ }^{45}$ Uo. VII. 2/b. 35. d. 359/1922.

${ }^{46}$ Uo. VII. 2/b. 36. d. 366/1922.
} 
azokat a bíróság a legtöbb esetben az elkövetési magatartásból vagy a vádlott és a sértett viszonyából vezette le. Az elkövetési magatartáshoz kapcsolódó súlyosbító körülmény lehetett tipikusan, ha a vádlott a büncselekményt késsel vagy szúró vágó eszközzel, ${ }^{47}$ pisztollyal, ${ }^{48}$ vasvillával, baltával, ${ }^{49}$ vagy mérgező anyag $^{50}$ felhasználásával követte el. Az elkövető és a sértett viszonyát egyrészt a jogalkotó is értékeli, másrészt a bíróság is. Az utóbbi esetben egyrészt a gyermek-szülő közötti kötelék szétzúzásához szükséges erkölcsi romlottságot, illetve aljas célképzetet értékelte a bíróság a vádlott terhére. Másrészt pedig az elkövető züllött, erkölcstelen életmódját is értékelte a bíróság. ${ }^{51}$

Összességében megállapítható, hogy a klasszikus iskola merev tanaira épülő Csemegi-kódex, a 20. században irányadó új büntetőjogi irányzatok fényében érvényesült. Mindez az ítélkezésben egy olyan „következetlenül következetes” ítélkezési gyakorlatot eredményezett, amelyben a bíróság a korábbinál nagyobb hangsúlyt fektetett az elkövető alanyi oldalának értékelésére.

\footnotetext{
${ }^{47}$ Uo. VII. 2/b. 34. d. 2218/1921.

${ }^{48}$ MNL HBML VII. 2/b. 34. d. 643/1923.; 36. d. 964/1922., 366/1922.

${ }^{49}$ Uo. VII. 2/b. 43. d. 497/1924.

${ }^{50}$ Uo. VII. 2/b. 43. d. 921/1924.; 295/1924.

${ }^{51}$ Uo. VII. 2/b. 36. d. 964/1922.; 43. d. 921/1924.
} 